\title{
Heterochromatin variation in Oziroë argentinensis (Hya- cinthaceae) revealed by florescent banding
}

\author{
Massimiliano Dematteis $^{1,2^{*}}$, Aveliano Fernández $^{1,2}$ and Andrea D. Acosta ${ }^{1}$ \\ ${ }^{1}$ Instituto de Botánica del Nordeste (UNNE-CONICET), Casilla de Correo 209, 3400 Corrientes, Argentina, \\ ${ }^{2}$ Facultad de Ciencias Exactas y Naturales y Agrimensura, Universidad Nacional del Nordeste, Corrientes, Argen- \\ tina.
}

\begin{abstract}
Previous studies in Oziroë argentinensis (Lillo et Hauman) Speta, have showed variation of heterochromatic regions between and within different populations of the species. In this study, were examined the heterochromatic regions of nine individuals obtained by vegetative propagation from a single plant in an attempt to determine possible modifications of the heterochromatin distribution after 14 years. The analyzed individuals have not showed differences in chromosome number and karyotype formulae respect to the parental plant. However, the Q-banding technique revealed a wide variation in number, position and size of the heterochromatic regions. The number of heterochromatic regions ranged between 11 and 15, differing from the parental plant that presented 14. The total amount of heterochromatin ranged between $6.25 \mu \mathrm{m}$ and $13.5 \mu \mathrm{m}$, which represent approximately $5.34 \%$ and 8.99 of the total karyotype length. Likewise, the distribution of the heterochromatic regions was considerably different in all the studied specimens, due to which has been not found two or more individuals with the same Q-banding pattern. The wide variation of the heterochromatic regions observed in this species could be explained through different mechanisms, such as tandem duplications, saltatory amplification and somatic cross-over.
\end{abstract}

Key words: heterochromatin, Hyacinthaceae Oziroë, Q-banding, variation.

\section{INTRODUCTION}

Almost all the genera of Liliales are known to possess important amounts of heterochromatin, distributed in segments of different size and location on the chromosomes. Heterochromatic segments have been found to be variable in both the number and type within populations of many species (Vosa 1973; 1985; 1996; BarbuJANI and PigliucCi 1989; TARDIF and Morisset 1991; Vosa and Stergianou 1990). Since the advent of banding techniques has become clear that the occurrence of quantitative differences in heterochromatic segments constitute probably the most common category of chromosome variation (JoHN 1981). However, there have been relatively few attempts to investigate heterochromatin variation patterns within populations or species (KENTON 1978; Barbujani and Pigliucci 1989; Tardif and MorisSet 1991).

\footnotetext{
* Corresponding author: fax: 54-3783-427131; e-mail: dematteisar@yahoo.com.ar
}

According to the typical definition, heterochromatin consists of chromosome material that maintains its anaphase condensation through interphase (HEITz 1929). Heterochromatin has been further defined as dispensable, non-transcribing, generally repetitive DNA and located in chromosomes as discrete, inheritable segments (VosA 1996). The constitutive heterochromatin may be positively recognized through differential staining of chromosomes with the standard C-banding technique (SCHWEIZER 1973; GreILHUBER 1984). The occurrence of C-bands has been well determined in many taxa of Liliales, including several species of the genera Allium (Vosa 1996; Cai and Chinappa 1987), Scilla (Greilhuber 1977; 1978; Greilhuber and SpETA 1976) and Ornithogalum (VosA 1997). In addition to the C-banding, some of these studies have obtained also quinacrine banding patterns (Vosa 1971; 1996; 1997; D'Amato 1986; BarbuJANi and Pigliucci 1989). Fluorescent banding make possible to obtain additional information on the heterochromatic regions, due to the fluorochromes have affinity to certain specific DNA base pairs (ChINNAPPA and Morton 1978; JoAchimiak et al. 1997). Particularly, the quina- 
crine intensity depends of the DNA base composition and repetitiveness. The presence of repetitive A-T nucleotides enhances the quinacrine fluorescence, while G-C base pairs effectively decrease it (Weisblum and de Haseth 1973; Vosa 1985).

Both $\mathrm{C}$ and $\mathrm{Q}$ banding patterns have been determined in two species of the genus Oziroë Raf. (FERnÁndez and Davina 1990, sub Fortunatia) and like some other plant groups (CHINAPPA and Morton 1978; Fukuda 1984), the two banding patterns have showed to be equivalent. The genus Oziroë contains six species distributed through the mountain regions of Chile, Peru, Bolivia and Argentina (Guaglianone and Arroyo-LeuenBERgER 1995; RAVENNA 1998; SPETA 1998; Guaglianone and Arroyo-Leuenberger 2002) and constitutes the single South American member of the Hyacinthaceae, a segregated family of Liliaceae. One of the most widely distributed species of the genus is Oziroë argentinensis (Lillo et Hauman) Speta, which has showed a wide heterochromatin variation between and within different populations (FERNÁNDEZ and DAvina 1990, sub Fortunatia biflora).

In this report, we present the Q-banding patterns of several individuals of $O$. argentinensis that has been produced by vegetative propagation from a single plant. The purpose of this study was to examine possible modifications in the heterochromatin distribution of the individuals after fourteen years.

\section{MATERIALS AND METHODS}

The analyzed specimens were obtained from a single plant collected at Mburucuyá, in the Argentinean province of Corrientes, that has been previously analyzed by FERNÁNDEZ and DAVINA (1990). The offspring's were produced by this plant since 1991 through natural vegetative propagation and has been maintained in the greenhouse under similar culture and environmental conditions.

For mitotic chromosome preparations, actively growing root-tips were pretreated during about 4-5 hours in 8-hydroxyquinoline $0.002 \mathrm{M}$ solution at room temperature and then fixed in acetic acid-ethanol (1:3). To obtain conventional preparations was generally applied the Feulgen's stain technique. Quinacrine fluorescent banding was accomplished according the schedule suggested by Vosa (1973). The observations of quinacrine stained preparations were realized using a Zeiss Axioplan microscope. Chromosomal measurements were estimated from photographic prints taken on Kodak Tri-X Pan 400 asa black and white film.

Nomenclature utilized for the karyotype description is that proposed Levan et al. (1964). Chromosome morphology was determined using the centromeric index ( $c i=$ short arm x $100 /$ total chromosome length). Accordingly, the chromosomes were classified in metacentrics $(\mathrm{m})$ : 50-37.5, submetacentrics $(\mathrm{sm}): 37.5-25$ and subtelocentrics (st): 25-12.5. The different chromosome parameters were obtained measuring at least of thirteen metaphase plates for each plant. For karyotype representation, the chromosomes were firstly arranged according to their morphology and within each group were ordered by decreasing size.

\section{RESULTS}

The analyzed plants presented a somatic chromosome number of $2 n=30$ and revealed the same standard karyotype composed of 8 metacentric, 16 submetacentric and 6 subtelocentric chromosomes (Figs. 5-14). The Q-banding pattern observed in the nine analyzed plants was notably different in all the cases (Figs. 1-4), showing variation not only in number but also in size and location of the heterochromatic regions (Figs. 5-14). The number of heterochromatic segments and the percentages of heterochromatin of each analyzed specimen are detailed in Table 1.

Heterochromatic regions varied in number between 11 and 15, however in all specimens only one Q-band per chromosome has been observed (Figs. 5-14). From the nine analyzed plants, two presented 15 heterochromatic regions $(7.2 ; 7.5)$, three plants showed 14 bands $(1.7 ; 3.4 ; 7.4)$, other two revealed $13(3.8 ; 1.17)$, one exhibited 12 heterochromatic regions (3.11) and the remaining 11 (1.11).

In addition, all the plants presented a different localization and size of the $\mathrm{Q}$ bands respect to the parental plant, due to which two or more individuals having the same Q-banding pattern were not found (Figs. 6-14). The total amount of heterochromatin ranged between $6.25 \mu \mathrm{m}$ and 13.5 $\mu \mathrm{m}$. Higher heterochromatin proportion was observed in the specimen 1.17 that showed a total of 13 banded chromosomes, which comprises 9.23 $\%$ of the total karyotype length. On the other hand, the individuals having the lower amount of heterochromatin (3.11) revealed 12 chromosomes with Q-bands (Fig. 2), which represents $5.34 \%$ of 

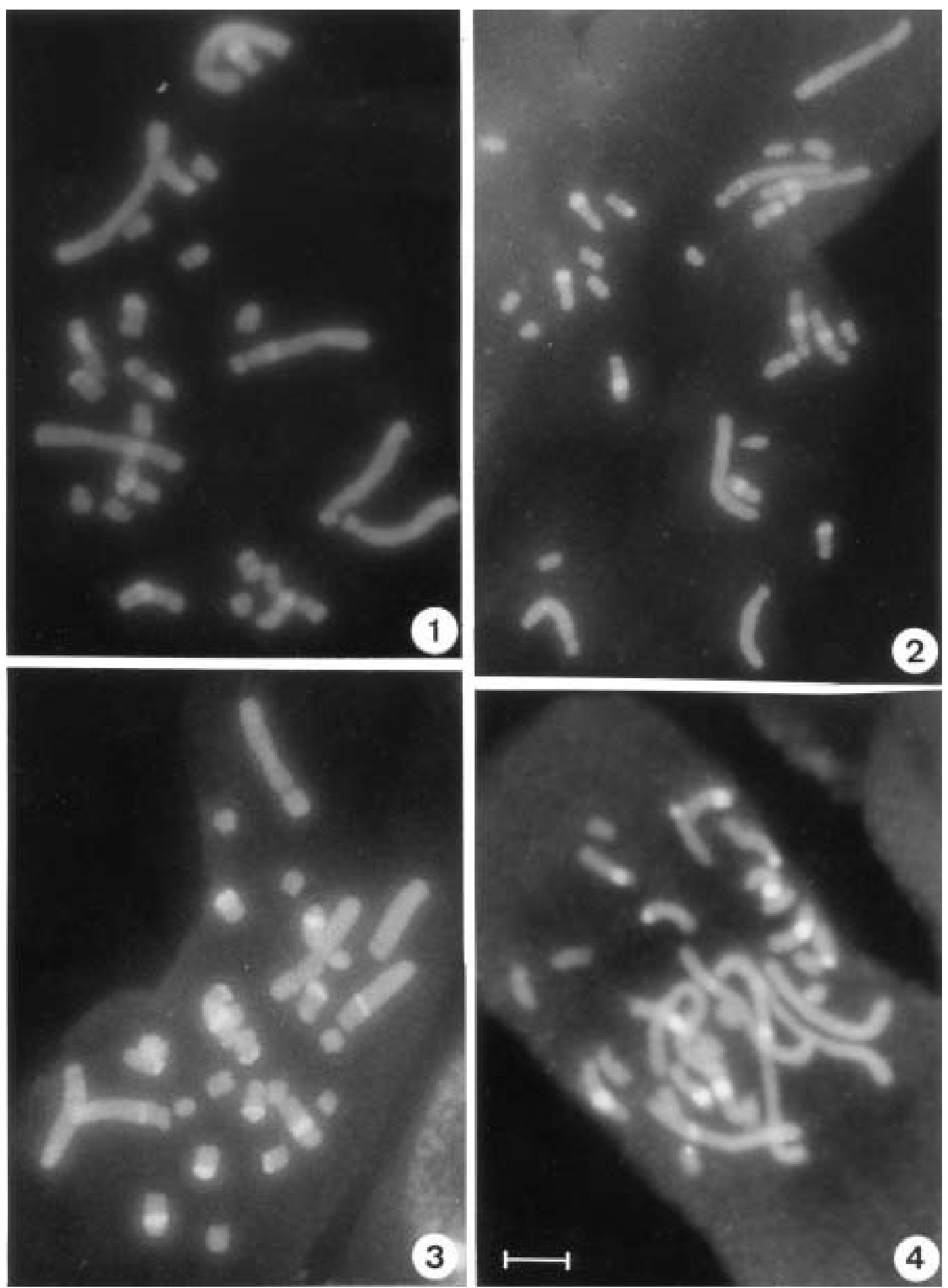

Figs. 1-4 - Mitotic chromosomes of O. argentinensis stained with quinacrine. 1. Metaphase plate showing 11 positive Q-bands in plant $n^{\circ}$ 1.11. 2. Metaphase plate with 12 bands in the specimen 3.11. 3-4. Metaphase of the individuals 3.8 (3) and 7.5 (4) having 13 and 15 positive Q-bands respectively. Scale $=5 \mu \mathrm{m}$. 
Table 1 - Number of chromosomes with heterochromatic regions $(\mathrm{CH})$, total quantity of heterochromatic regions (HT), total chromosome length (TCL), mean length of heterochromatic regions in $\mu \mathrm{m}$ (HL) and percentage of the TCL with heterochromatic regions (\% HR) of the analyzed plants.

\begin{tabular}{cccrrr}
\hline Individuals & $\mathrm{CH}$ & $\mathrm{HT}$ & $\mathrm{TCL} \pm \mathrm{ES}$ & $\mathrm{HL} \pm \mathrm{ES}$ & $\% \mathrm{HR} \pm \mathrm{ES}$ \\
\hline 1.7 & 14 & 14 & $64.61 \pm 2.21$ & $13.00 \pm 0.44$ \\
1.11 & 11 & 11 & $71.08 \pm 3.16$ & $9.25 \pm 0.45$ \\
1.17 & 13 & 13 & $63.83 \pm 1.76$ & $7.25 \pm 0.21$ \\
3.4 & 14 & 14 & $60.25 \pm 1.31$ & $10.75 \pm 0.14$ \\
3.8 & 13 & 13 & $53.99 \pm 2.54$ & $6.75 \pm 0.28$ \\
3.11 & 12 & 12 & $54.20 \pm 1.92$ & $6.25 \pm 0.24$ & $8.23 \pm 0.27$ \\
7.2 & 15 & 15 & $74.51 \pm 3.72$ & $13.50 \pm 0.67$ & $6.52 \pm 0.27$ \\
7.4 & 14 & 14 & $63.45 \pm 1.49$ & $12.50 \pm 0.28$ \\
7.5 & 15 & 15 & $71.65 \pm 2.77$ & $9.75 \pm 0.34$ & $5.59 \pm 0.44$ \\
\hline
\end{tabular}

$\mathrm{ES}=$ standard error

its karyotype length. Due to the earlier differences, the proportion of the total karyotype length with heterochromatin was considerably different in all plants (Table 1).

\section{DISCUSSION}

The chromosome number and karyotypic features of the analyzed specimens have not showed differences respect to the parental plant. However, it revealed a considerable variation in number, size and distribution of the Q-bands. As result of the Q-banding pattern differences, individuals with the same number of heterochromatic blocks always present different location of the bands and/or different heterochromatin amount.

The Q-bands number found in the present study varied between 11 and 15, which differ considerably from the parental plant that showed a total of 14 bands distributed on 7 chromosome pairs (Fernández and Davina 1990). Such number of Q-bands was detected here only in three plants, while the remaining individuals presented a different number of heterochromatic regions.

High levels of heterochromatin polymorphism have been described for other genera of Monocots that mostly belong to the large family Liliaceae (Vosa 1973; 1985; Fukuda 1984; Cai and Chinappa 1987; Barbujani and Pigliucci 1989; Vosa and Stergianou 1990; Tardif and Morisset 1991). Several studies on heterochromatin variation suggest that it could have an important adaptative function. In some cases, the heterochromatin seems to constitute a compensating factor that influences the cell cycle duration and the relative growth speed (Nagl 1974; Vosa and Stergianou 1990). Another reason for the presence of heterochromatin can be found in its effects on genetic recombination, which are known to occur in plants (RHOAdEs 1978) and in animals (JoHN and Miklos 1979; Miklos and Nankivell 1976). Heterochromatin content differences in some Liliaceae genera have been correlated with vegetative characters such as the timing of the development of the flower spike, leaf emergence and seed-capsule ripening (Vosa 1997). Chromosome analysis of some populations of Allium pulchellum G.Don collected at different altitude indicates that heterochromatin would enable the species to colonize relatively higher ground (VosA 1996). However, the heterochromatin differences found in $O$. argentinensis have not apparently an adaptative role, because the individuals analyzed here were derived of a single plant by vegetative reproduction and all them has been cultivated at the greenhouse under similar environmental conditions.

Heterochromatin variations involving the number and distribution of segments have been attributed to different mechanisms. Heterochromatin polymorphism found in Triticum was explained as combination of different mechanisms concentrated in the repetitive DNA sequences that constitute the heterochromatic segments (FrIEBE et al. 1992). The large polymorphism observed in the genus Scilla, when the chromosomes are heteromorphic for different number of bands, has been attributed to tandem duplications (Greilhuber and Speta 1976). For the genus Allium, C-banding variations have been related to transposition events, which would be responsible of the chromosome rearrangements that change the C-banding patterns (SCHUbert and Wobus 1985). The heterochromatin changes at telomeres of Secale, has been assumed to be result of saltatory amplification events on one or more chromosomes followed by unequal crossing-over between homologues and perhaps non-homologues (BENNET et al. 1977). Heterochromatin addition at tel- 
5 ำ ำ

m

sm

st

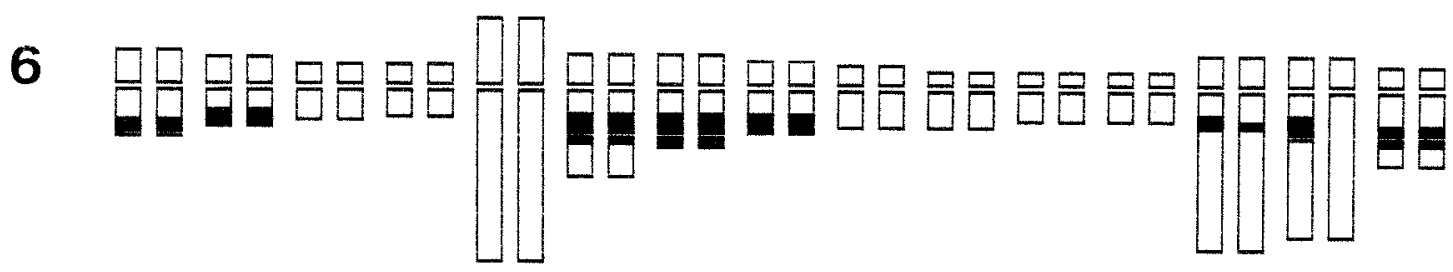

m

Sm

st

7 月

$\begin{array}{llc}\mathrm{m} & \mathrm{sm} & \text { st }\end{array}$

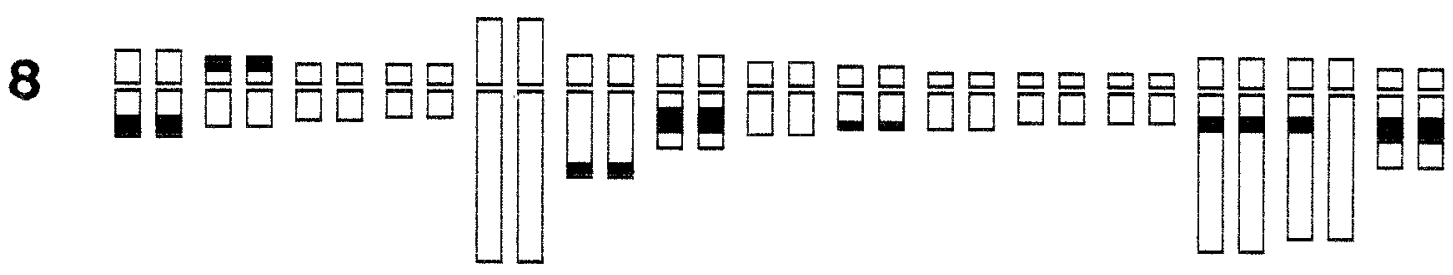

m $\quad$ sin $\quad s t$

9

In

$\operatorname{sm}$

st

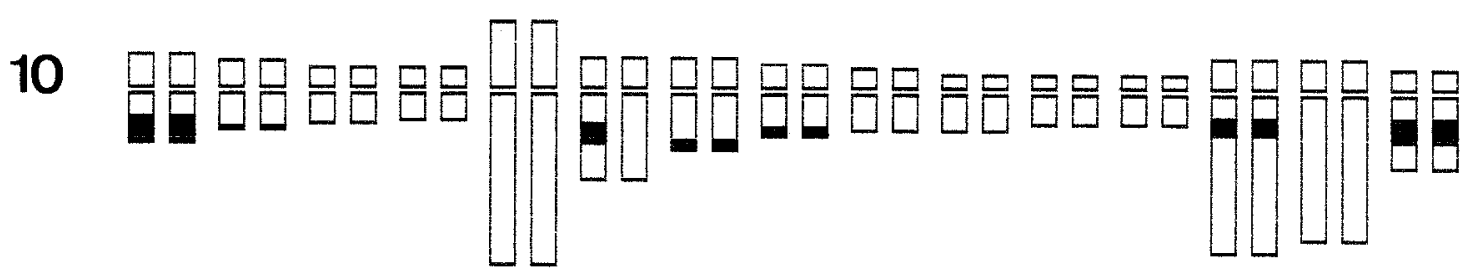

$\mathbf{m}$

sm

st

Figs. 5-10 - Q-banding pattern in different plants of Oziroë argentinensis. 5. Parental specimen. 6-10. Individuals $n^{\circ}$ $7.2(\mathbf{6}), 7.4(\mathbf{7}), 7.5(\mathbf{8}), 3.4(\mathbf{9})$ and $3.8(\mathbf{1 0})$ respectively. Scale $=5 \mu \mathrm{m}$. 


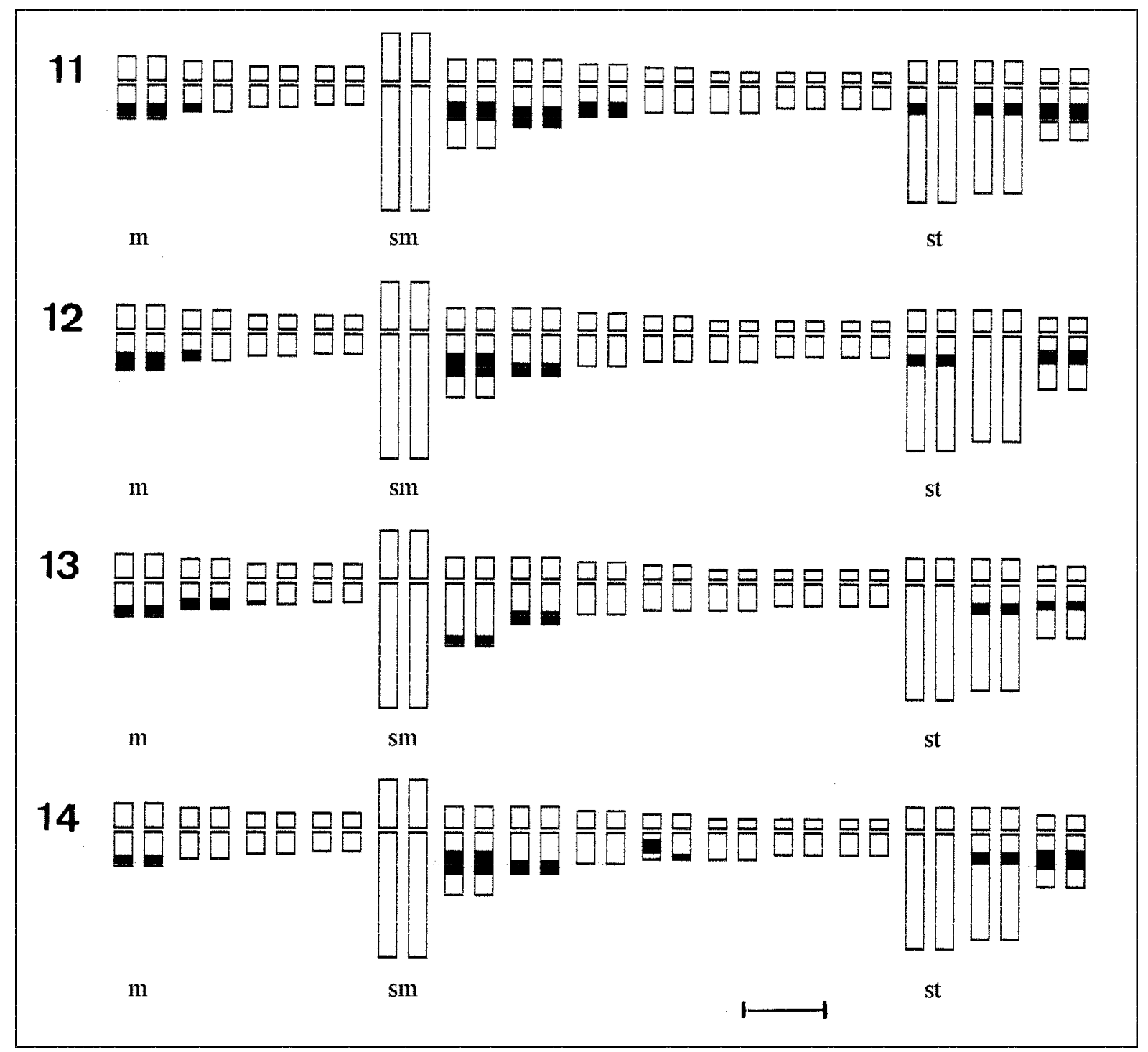

Figs. 11-14 - Q-banding pattern in plants $n^{\circ} 1.7(\mathbf{1 1}), 1.11(\mathbf{1 2}), 1.17$ (13) and 3.11 (14) of Oziroë argentinensis. Scale $=5 \mu \mathrm{m}$.

omeres would be produced by saltatory amplification, while unequal crossing-over may could have played a secondary role in distributing the newly amplifies sequences to telomeres through the karyotype (BENNET et al. 1977). Although the frequency of unequal crossing-over is commonly very low, the finding of homologue somatic recombination (HUTTNER and RUDDLE 1976), could increase considerably its probability of occurrence. Another factor that could increase this phenomenon is the chromosome disposition into the nucleus. In many plant groups has been observed a bouquet configuration when telomeres are located at the same area of the nuclear membrane, which could facilitate the occurrence of somatic cross-over (BENNET et al. 1977).
The banding pattern observed in Oziroë argentinensis indicates that the heterochromatic regions variation comprises chromosome segments mostly located at telomeric region of the chromosomes. The heterochromatin differences could have been produced by one or more mechanisms mentioned above. The absence of karyotypic differences between individuals suggests that duplications or deletions are probably not implicated. A possible explanation would be certainly the occurrence of somatic cross-over between homologue and non homologue chromosomes. This could be partially supported by the presence of some heteromorphic pairs and the Q-bands size differences between homologue chromosomes. 
The differences in heterochromatin amount between some homologous chromosomes, are commonly attributed to unequal crossing-over caused by erroneous pairing at meiosis, which may lead to increasing or decreasing of the size of the heterochromatic regions (Sмiтн 1976). The individuals analysed here have been obtained by vegetative propagation, due to which should be considered alternative explanations, such as heterochromatinization processes (KING 1980) and somatic cross-over (BENNET et al. 1977). However, to determine exactly the mechanism involved in the generation of the variations would be necessary to realize additional studies.

\section{REFERENCES}

Barbujani G. and Pigliucci M., 1989 - Geographical patterns of karyotype polymorphism in Italian populations of Ornithogalum montanum (Liliaceae). Heredity, 62: 67-75.

Bennett M.D., Gustafson J.P. and Smith J. B., 1977 - Variation in nuclear DNA in the genus Secale. Chromosoma (Berl.), 61: 149-176.

Cai Q. and Chinnappa C.C., 1987 - Giemsa C-banded karyotypes of seven North American species of Allium. Amer. J. Bot., 74: 1087-1092.

Chinnappa C.C. and Morton J. K., 1978 - Heterochromatic banding patterns in two species of Trillium. Canad. J. Genet. Cytol., 20: 475-481.

D’Aмaто G., 1986 — Different types of heterochromatin in plant chromosomes investigated by Feulgen banding. Caryologia, 39: 123-129.

FernÁndez A. and DAvina J.R., 1990 - Heterochromatin and genome size in Fortunatia and Camassia (Hyacinthaceae). Kew Bull., 46(2): 307-316.

Friebe B., Mukai Y. and Gill B.S., 1992 - C-banding polymorphism in several accessions of Triticum tauschii (Aegilops squarrosa). Genome, 35: 192-199.

Fukuda I., 1984 - Chromosome banding and biosystematics. In: W.F. Grant (ed.), "Plant biosystematics". Academic Press, London.

Greilhuber J., 1977 - Nuclear DNA and beterochromatin contents in the Scilla hohenackeri group, $S$. persica and Puschkinia scilloides (Liliaceae). Pl. Syst. Evol., 128: 243-257.

-, 1978 - DNA contents, giemsa banding, and systematics in Scilla bifolia, S. drunensis and S. vindobonensis (Liliaceae). Pl. Syst. Evol., 130: 223-233.

—, 1984 - Chromosomal evidence in taxonomy. In: V.H. Heywood and D.M. Moore (eds.), "Current concept in plant taxonomy”. p. 157-180. Academic Press, London.

Greilhuber J. and Speta F., 1976 - C banded karyotypes in the Scilla hobenackeri group, S. persica and Puschkinia (Liliaceae). Pl. Syst. Evol., 126: 149-188.

Guaglianone E.R. and Arroyo-Leuenberger A., 1995 - Nueva combinación en Fortunatia (Liliaceae). Hickenia, 2(31): 137-138.
—, 2002 - The South American genus Oziroë (Hyacinthaceae, Oziroëoideae). Darwiniana, 40: 61-76.

HeItz E., 1929 - Heterochromatin, Chromocentren, Chromomeren. Ber. Deutsch. Bot. Ges., 47: $274-$ 284.

HutTner K.M. and Ruddle F.H., 1976 - Study of mitomycin $C$ induced chromosomal exchange. Chromosoma (Berl.), 56: 1-13.

Joachimiak A., Kula A. and Grabowska-Joachimiak A., 1997 - On beterochromatin in karyosystematic studies. Acta Biol. Cracov., ser. Bot., 39: 69-77.

JoHn B., 1981 - Heterochromatin variation in natural populations. Chromosomes Today, 7: 128-137.

JoHn B. and MikLos G.L.G., 1979 - Functional aspects of heterochromatin and satellite DNA. Int. Rev. Cytol., 58: 1-114.

Kenton C., 1978 - Giemsa C banding in Gibasis (Commelinaceae). Chromosoma (Berl.), 65: 309-324.

Levan A., Fredga K. and Sandberg A.A., $1964-$ Nomenclature for centromeric position on chromosomes. Hereditas, 52: 201-220.

Miklos G.L.G. and Nankivell R.N., 1976 - Telomeric satellite DNA functions in regulating recombination. Chromosoma (Berl.), 56: 143-167.

NAGL W., 1974 - Role of heterochromatin in the control of the cell cycle duration. Nature, 249: 53-54.

Ravenna P., 1998 - Oziroë antedating Fortunatia (Hyacinthaceae) and a new species from Argentina. Onira, 3(14): 40-41.

RhoAdes M.M., 1978 - Genetic effects of heterochromatin in maize. In: D.B. Walden (ed.), "Maize breeding and genetics”. p. 541-571. New York.

Schubert I. and Wobus U., 1985 - In situ bybridization confirms jumping nucleolus organizing regions in Allium. Chromosoma (Berl.), 92: 143-148.

SChweIzer D., 1973 - Differential staining of plant chromosomes with giemsa. Chromosoma (Berl.), 40: 307-320.

Sмith G.P., 1976. - Evolution of repeated DNA sequences by unequal crossover. Science, 191:528-535.

SPETA F., 1998 - Systematische Analysis der Gattung Scilla L. s.l. (Hyacinthaceae). Phyton (Horn), 38: $1-141$.

TARdif B. and Morisset P., 1991 - Chromosomal C band in Allium schoenoprasum (Liliaceae) in eastern North America. Pl. Syst. Evol., 174: 125-137.

Vosa C., 1971 - The quinacrine-fluorescence patterns of the chromosome of Allium carinatum. Chromosoma (Berl.), 33: 382-385.

-, 1973 - Heterochromatin recognition and analysis of chromosome variation in Scilla sibirica. Chromosoma (Berl.), 43: 269-278.

-, 1985 - Chromosome banding in plants. In: A.K. Sharma and A. Sharma (eds.), "Advances in chromosome and cell genetics”. p. 79-104. Oxford \& IBH Publishing Co, New Dehli.

—, 1996 - Some aspects of karyotype evolution in Liliflorae: beterochromatin variation and ecology in Allium pulchellum. Bocconea, 5(1): 267-270. 
—, 1997 - Heterochromatin and ecological adaptation in Southern African Ornithogalum (Liliaceae). Caryologia, 50(2): 97-103.

Vosa C. and Stergianou C., 1990 - The cytoecology of the genus Pleinoe. J. Orchid Soc. India, 4: 29-35.
Weisblum B. and de Haseth P.L., 1973 - Nucleotide specificity of the Quinacrine reaction for chromosomes. Chromosomes Today, 4: 35.

Received 25.03.2005; accepted 11.01.2006 